\title{
FORMULASI IDE PERMAAFAN HAKIM (RECHTERLIJ K PARDON) DALAM PEMBAHARUAN SISTEM PEMIDANAAN DI INDONESIA
}

\author{
Aristo Evandy A.Barlian'1, Barda Nawawi Arief 2 \\ Program Studi Magister IImu Hukum \\ Fakultas Hukum Universitas Diponegoro \\ ena_feriana@yahoo.co.id
}

\begin{abstract}
ABSTRAK
Substansi Buku 1 Kuhp saat ini merupakan pedoman induk dalam sistem pemidanaan di Indonesia, namun pedoman dalam perumusan pidana saat ini hanya terpaku pada ketentuan adanya tindak pidana dan kesalahan tanpa memasukan tujuan dan asas dari pemidanaan.Oleh karena itu hukum pidana saat ini dirasa kaku dan tidak berkemanusiaan dalam aplikasinya pada kasus-kasus kecil yang dipandang memerlukan keadilan sosial. Rumusan sistem induk yang tidak memilki tujuan dan asas dalam pedoman pemidanaan tidak akan melahirkan hukum yang efektif, saat ini telah hadir sebuah ide yaitu Rechterlijk Pardon sebagai salah satu konsep dalam pembaharuan pidana yang telah digunakan oleh pelbagai negara yang menerapkan civil law sistem. Penelitian ini bertujuan untuk menganalisis ide Rechterlijk Pardon dalam tahap formulasi dan aplikasi yang ada pada saat ini dan dalam formulasi sistem induk pidana yang akan datang di Indonesia. Metode pendekatan yang digunakan penulis adalah penelitian hukum kualitatif normatif, yaitu dengan pendekatan perundang-undangan (statute appproach), pendekatan konseptual (conceptual approach), Pendekatan kasus (case approach) dan pendekatan perbandingan (comparative approach). Analisis kualitatif normatif terhadap data yang disajikan secara kuantitatif, berpijak pada analisis deskriptif dan prediktif. Hasil analisa pada penelitian ini ditemukannya 6 (enam) pasal yang berkaitan dengan nilai permaafan dalam formulasi kuhp saat ini namun bukanlah nilai permaafan yang murni dan ditemukannya 5 (lima) aplikasi peradilan pidana yang telah memiliki nilai permaafan namun masih belum dapat diterapkan dengan baik karena tidak adanya formulasi permaafan dalam pidana saat ini. Diformulasikannya ide permaafan hakim "Rechterlijk Pardon" dengan memasukannya tujuan dan asas pemidanaan dalam syarat pemidanaan yaitu pada Pasal 55,56 dan 72 RUU KUHP 2015, nantinya akan menjadikan sistem hukum pidana di Indonesia yang akan datang dapat lebih integral, fleksible, humanis, progress dan nasionalis. Disarankan kepada anggota Parlemen untuk dapat membuat dan melegitimasi rancangan perumusan sistem hukum pidana yang telah ada sampai sekarang. Mereformasi sistem hukum pidana merupakan bagian penting dalam perkembangan sistem peradilan pidana di masa depan. sistem peradilan pidana sangat membutuhkan reformasi yang signifikan seperti masuknya tujuan dan asas hukum pidana sehingga terwujudnya sistem peradilan pidana yang efektif di Indonesia.
\end{abstract}

\section{Kata Kunci : Formulasi Sistem Pemidanaan; Ide Permaafan Hakim; Pembaharuan Hukum}

\footnotetext{
${ }^{1}$ Mahasiswa Program Studi Magister IImu Hukum UNDIP

2 Penulis Kedua, Penulis Koresponden
} 


\section{A. Pendahuluan}

Kebijakan formulasi dalam perumusan sistem pemidanaan materiil di Indonesia pada saat ini (Kuhp/WvS) berasal dari warisan jajahan belanda yang penyusunannya lebih berorientasi pada pelaku tindak pidana.Nilai filosofi yang menjadi latar belakang disusunnya Kuhp/WvS adalah individualism dan liberalism yang dilihami oleh aliran klassik/neo klassik yang berorientasi pada perbuatan dan pelaku tindak pidana. Ketentuan perundang-undangan hukum pidana materiil di Indonesia tidak dapat dipisah-lepaskan dengan "Ketentuan Induk" dari Kuhp/WvS dan ketentuan UU pidana diluar Kuhp. ${ }^{3}$

Saat ini sedang disusun Konsep KUHP Baru yang bertujuan menggantikan KUHP/WvS karena ide/konsep dasar pemikiran, nilai filosofi dalam masa penyusunannya, sudah tidak sesuai lagi dengan ide/konsep dasar pemikiran, nilai filosofi yang disusun dalam Konsep. Ide/konsep dasar pemikiran, nilai filosofi disusunnya Konsep adalah Pancasila yang jalinan ide dalam setiap silanya mencerminkan Nilai Ketuhanan, Nilai Kemanusiaan dan Nilai Kemasyarakatan.

Dalam konsep terdapat Pembaharuan ide yang merupakan kebijakan formulasi dan salah satunya adalah "ide permaafan oleh hakim" ide

${ }^{3}$ Barda Nawawi Arief, RUU KUHP BARU sebuah Restrukturisasi/R ekonstruksi Sistem Hukum Pidana Indonesia, Penerbit Pustaka. Magister, Semarang 2012, hlm.1-2. tersebut merupakan terobosan hukum baru yang diatur dalam konsep.Ide tersebut lebih memiliki cakupan nilai-nilai hukum yang hidup dan nilai hukum nasional yang lebih berorientasi pada nilai Pancasila. Saat ini KUHP/ Wvs sama sekali tidak mengatur adanya ketentuan umum mengenai dapatnya dilakukan permaafan oleh hakim. Akibatnya banyak kasus-kasus kecil seperti pencurian kakao, sandal, semangka dijatuhi pidana yang tidak sesuai, bahkan bertentangan dengan nilai-nilai kemanusiaan yang hidup di masyarakat. ${ }^{4}$ Permaafan oleh hakim juga dikenal sebagai Rechterlijk pardon, non imposing of penalty, Judicial Pardon atau dispensa de pena. Diberbagai negara, dalam hal tertentu hakim dapat untuk tidak menjatuhkan pidana terhadap pelaku tindak pidana. Gagasan mengenai permaafan hakim dalam Konsep RUU KUHP merupakan nilai hukum terbaru yang merupakan reformasi dari kekakuan sistem pemidanaan dalam KUHP/Wvs. Sistem pemidanaan dalam KUHP mensyaratkan bahwa pidana dapat dijatuhkan apabila terpenuhi syarat adanaya perbuatan dan kesalahan. Dengan bertumpu pada dua syarat tersebut maka pemidanaan dalam KUHP dirasakan sangat kaku dan tidak progress dalam menyelesaikan

\footnotetext{
4Barda Nawawi Arief, Pembaharuan Sistem Penegakan Hukum Dengan Pendekatan Religius Dalam Konteks Siskumnas Dan Bangkumnas, Semarang, hlm.10.
} 
problematika penegakan hukum dalam pendekatan kasus.Analisis kualitatif normatif pembaharuan hukum nasional. ${ }^{5}$

terhadap data yang disajikan secara kuantitatif,

Berdasar pada uraian dalam "latar berpijak pada analisis deskriptif dan prediktif.

belakang" di atas, maka penulisan ini hendak

menganalisis tentang "Formulasi ide Permafaan

Hakim (Rechterlijk Pardon) dalam Pembaharuan

Sistem Pemidanaan di Indonesia" untuk memberikan kebebasan kepada hakim dalam memutus perkara-perkara yang semestinya dapat diselesaikan dan didamaikan secara cepat oleh hakim, serta memperluas kewenangan hakim dalam mencari dan menggali keadilan yang hakiki berdasarkan ketuhanan yang maha esa.

\section{B. Metode Penelitian}

Metode pendekatan dalam penelitian ini adalah penelitian hukum kualitatif normatif. Dalam penelitian hukum normatif digunakan beberapa pendekatan, yaitu pendekatan perundangundangan (statute approach), pendekatan konseptual (conceptual approach), Pendekatan kasus (case approach) dan pendekatan perbandingan (comparative approach.)6. Penggunaan metode analisis kualitatif normatif ini sangat berkaitan dengan permasalahan yang dibahas dalam pendekatan perbandingan dan

${ }^{5}$ Barda Nawawi Arief, Masalah Penegakan Hukum dan Kebijakan Penanggulangan Kejahatan. Program Magister IImu Hukum Undip, .hIm. 79.

6Johnny Ibrahim, 2005.Teori dan Metodologi Penelitian Hukum Normatif, Bayumedia Publishing, Surabaya, hlm.444.

\section{Pembahasan}

\section{Kebijakan Formulasi Hukum pidana saat ini} yang berorientasi pada nilai permaafan.

Dalam meninjau adanya permaafan hakim pada substansi Kuhp saat ini beberapa pasal dibawah menunjukan adanya kemungkinan permaafan dari hakim, namun dapat diketahui apakah pasal-pasal diatas memang telah memenuhi unsur dari nilai permaafan yang sesungguhnya yang dapat memberi pedoman bagi hakim melakukan permaafan. 


\begin{tabular}{|c|c|c|c|c|c|}
\hline No & $\begin{array}{l}\text { Kebijakan } \\
\text { Formulasi }\end{array}$ & Pidana Ringan & Nilai Peramaafan & Kelemahan Hukuman & Hasil \\
\hline 1. & $\begin{array}{l}\text { KUHP/WvS } \\
\text { Pasal 14a ayat } \\
\text { (1). }{ }^{7}\end{array}$ & $\begin{array}{l}\text { Terhadap pidana satu } \\
\text { tahun penjara atau } \\
\text { kurungan. }\end{array}$ & $\begin{array}{l}\text { Hakim dapat } \\
\text { memerintahkan bahwa } \\
\text { pidana tidak usah } \\
\text { dijalani, }\end{array}$ & $\begin{array}{l}\text { Apabila syarat percobaan } \\
\text { tidak terpenuhi terpidana } \\
\text { tetap akan dipenjara dan } \\
\text { menjalani hukuman. }\end{array}$ & $\begin{array}{l}\text { Tidak ada nilai permaafan hakim dalam } \\
\text { ketentuan pidana percobaan atau pidana } \\
\text { bersyarat. }\end{array}$ \\
\hline 2 & $\begin{array}{l}\text { KUHP/WvS } \\
\text { Pasal } 40^{8}\end{array}$ & $\begin{array}{l}\text { Terhadap larangan } \\
\text { memasukan barang } \\
\text { bagi anak dibawah } \\
\text { umur. }\end{array}$ & $\begin{array}{l}\text { Diserahkan kembali } \\
\text { tanpa pidana apapun. }\end{array}$ & $\begin{array}{l}\text { Hakim dapat untuk tetap } \\
\text { memberi hukuman } \\
\text { pidana perampasan bagi } \\
\text { anak. }\end{array}$ & $\begin{array}{l}\text { Tidak ada nilai permaafan hakim dalam } \\
\text { pidana perampasan bagi anak. }\end{array}$ \\
\hline 3 & $\begin{array}{l}\text { UU pidana } \\
\text { Khusus diluar } \\
\text { KUHP No. } 11 \\
\text { Tahun } 2012 \\
\text { dalam Pasal } \\
70 .{ }^{9} \\
\end{array}$ & $\begin{array}{l}\text { Terhadap ringannya } \\
\text { perbuatan dan } \\
\text { keadaan pribadi Anak }\end{array}$ & $\begin{array}{l}\text { Hakim dapat } \\
\text { mempertimbangkan } \\
\text { untuk tidak } \\
\text { menjatuhkan pidana. }\end{array}$ & $\begin{array}{l}\text { Hakim dapat untuk tetap } \\
\text { memberikan hukuman } \\
\text { "Tindakan" bagi anak. }\end{array}$ & $\begin{array}{l}\text { Tidak ada nilai permaafan hakim dalam } \\
\text { pidana tindakan bagi anak. }\end{array}$ \\
\hline 4 & $\begin{array}{l}\text { KUHP } M V S \\
\text { Pasal } 82 .{ }^{10}\end{array}$ & $\begin{array}{l}\text { Terhadap hukuman } \\
\text { pelanggaran yang } \\
\text { dapat dibayar dengan } \\
\text { denda. }\end{array}$ & $\begin{array}{l}\text { Apabila denda telah } \\
\text { dibayar, kewenangan } \\
\text { menuntut pelanggaran } \\
\text { menjadi hapus. }\end{array}$ & $\begin{array}{l}\text { Bukan hakim pengadilan } \\
\text { yang memiliki } \\
\text { kewenangan } \\
\text { mendamaikan melainkan } \\
\text { lembaga Afkoop diluar } \\
\text { pengadilan, selain itu } \\
\text { adanya denda } \\
\text { maksimum yang } \\
\text { bercirikan adanya } \\
\text { permaafan atau } \\
\text { perdamaian bersyarat. }\end{array}$ & $\begin{array}{l}\text { Tidak ada nilai permaafan hakim dalam } \\
\text { pemberian pidana denda maksimum. }\end{array}$ \\
\hline 5. & $\begin{array}{l}\text { KUHP/WvS, } \\
\text { Pasal 44-51. }{ }^{11}\end{array}$ & $\begin{array}{l}\text { Terhadap hukuman } \\
\text { yang memiliki alasan } \\
\text { pemaaf. }\end{array}$ & $\begin{array}{l}\text { Apabila memiliki unsur } \\
\text { "adanya alasan } \\
\text { pemaaf" maka hakim } \\
\text { dapat menilai dengan } \\
\text { memutuskan untuk } \\
\text { menghapus dan } \\
\text { mengurangi pidana. }\end{array}$ & $\begin{array}{l}\text { Apabila tidak ada unsur } \\
\text { "adanya alasan pemaaf" } \\
\text { maka pidana tetap } \\
\text { dijalankan dengan alasan } \\
\text { "tiada maaf bagimu". }\end{array}$ & $\begin{array}{l}\text { Tidak ada nilai permaafan, karena dalam } \\
\text { rumusan hakim seharusnya tetap dapat } \\
\text { memaafkan sekalipun tiada alasan pemaaf } \\
\text { sekalipun. }\end{array}$ \\
\hline 6. & $\begin{array}{l}\text { KUHP/WvS } \\
\text { Pasal 33a dan } \\
\text { UU No. 22 } \\
\text { Tahun 2002.12 }\end{array}$ & $\begin{array}{l}\text { Terhadap hukuman } \\
\text { penjara yang } \\
\text { ditetapkan, paling } \\
\text { rendah } 2 \text { tahun. }\end{array}$ & $\begin{array}{l}\text { Diberikannya } \\
\text { penghapusan } \\
\text { pelaksanaan pidana } \\
\text { oleh Presiden. }\end{array}$ & $\begin{array}{l}\text { Terdapat kelemahan dari } \\
\text { fungsi pengadilan } \\
\text { khususnya kewenangan } \\
\text { hakim dalam memberi } \\
\text { maaf. }\end{array}$ & $\begin{array}{l}\text { Tidak ada nilai permaafan bagi hakim dalam } \\
\text { Grasi yang diberikan Presiden. }\end{array}$ \\
\hline
\end{tabular}

\footnotetext{
7 KUHP/WvS Pasal 14A ayat (1) tentang Ketentuan pidana percobaan atau pidana bersyarat dikutip pada 25 Juni 2016 pk.09.00 wib.

${ }^{8}$ KUHP/WvS Pasal 40 tentang pelanggaran terhadap anak dibawah umur pada 25 Juni 2016 pk.09.00 wib.

9 Undang-undang No.11 Tahun 2011 tentang sistem peradilan anak pada Pasal 70, dikutip pada 25 Juni 2016 pk.09.00 wib.

10 KUHP/WvS Pasal 82 tentang Pelanggaran yang diancam denda, dikutip pada 25 Juni 2016 pk.09.00 wib.

11 KUHP/WvS Pasal 44-51 tentang alasan pemaaf umur pada 25 Juni 2016 pk.09.00 wib.

12 KUHP/WvS Pasal 33A tentang Permohonan kepada Presiden dikutip pada 25 Juni 2016 pk.09.00 wib.
} 


\begin{tabular}{|c|c|c|c|c|c|c|}
\hline No. & Kasus & Masalah & Dakwaan & Nilai Permaafan & Putusan & Hasil \\
\hline 1. & $\begin{array}{l}\text { Ibu } \\
\text { Meneria }{ }^{13}\end{array}$ & $\begin{array}{l}\text { Meminjamkan uang ke } \\
\text { rekan-rekannya untuk } \\
\text { menafkahi anak- } \\
\text { anaknya. }\end{array}$ & $\begin{array}{l}\text { Didakwa hukuman } 1 \\
\text { tahun karena melakukan } \\
\text { kejahatan membuka } \\
\text { bank gelap tanpa izin } \\
\text { sesuai UU perbankan. }\end{array}$ & $\begin{array}{l}\text { Dinilai bersalah dan melawan } \\
\text { hukum, tetapi tidak ada motif } \\
\text { dan tujuan melakukan pidana, } \\
\text { orientasi hakim disini sudah } \\
\text { melihat pemidanaan dari } \\
\text { perbuatan ke pelaku tindak } \\
\text { pidana. }\end{array}$ & Lepas & $\begin{array}{l}\text { Tidak ada nilai } \\
\text { permaafan } \\
\text { hakim dalam } \\
\text { putusan Lepas. }\end{array}$ \\
\hline 2. & Juan $^{14}$ & Perkelahian & $\begin{array}{l}\text { Didakwa telah melakukan } \\
\text { Penganiayaan. }\end{array}$ & $\begin{array}{l}\text { Hakim banding mengupayakan } \\
\text { perdamaian antara terdakwa } \\
\text { dan keluarga korban secara } \\
\text { adat dan agama dengan } \\
\text { mengutip al-Baqarah: } 178 \text {. }\end{array}$ & Percobaan & $\begin{array}{l}\text { Tidak ada nilai } \\
\text { permaafan } \\
\text { hakim dalam } \\
\text { putusan } \\
\text { percobaan. }\end{array}$ \\
\hline 3. & $\begin{array}{l}\text { Boni }\left(16^{\text {Th }}\right) \\
15\end{array}$ & $\begin{array}{l}\text { Kelalaian mengendarai } \\
\text { motor yang meng- } \\
\text { akibatkan kematian. }\end{array}$ & $\begin{array}{l}\text { Didakwa } 6 \text { bulan penjara } \\
\text { dan denda, karena } \\
\text { kelalaian yang } \\
\text { menimbulkan kematian. }\end{array}$ & $\begin{array}{l}\text { Hakim menawarkan } \\
\text { perdamaian kepada keluarga } \\
\text { korban dengan menimbang } \\
\text { usia boni dan melihat usaha } \\
\text { boni untuk menyelamatkan } \\
\text { korban saat kecelakaan terjadi. }\end{array}$ & Percobaan & $\begin{array}{l}\text { Tidak ada nilai } \\
\text { permaafan } \\
\text { hakim dalam } \\
\text { putusan } \\
\text { percobaan. }\end{array}$ \\
\hline 4. & Aal $\left(15^{\text {Th }}\right)$ & $\begin{array}{l}\text { Mencuri sepasang } \\
\text { sandal. }\end{array}$ & $\begin{array}{l}\text { Didakwa pencurian pada } \\
\text { sandal pegawai Polisi. }\end{array}$ & $\begin{array}{l}\text { Hakim menimbang adanya } \\
\text { kesadaran anak untuk } \\
\text { mengakui kesalahannya dan } \\
\text { menimbang pengaruh pidana } \\
\text { pada masa depan pelaku. }\end{array}$ & $\begin{array}{l}\text { Tindakan } \\
\text { pengembalian } \\
\text { kepada orangtua }\end{array}$ & $\begin{array}{l}\text { Tidak ada nilai } \\
\text { permaafan } \\
\text { hakim dalam } \\
\text { hukuman } \\
\text { Tindakan. }\end{array}$ \\
\hline 5. & Ellya Dado ${ }^{16}$ & $\begin{array}{l}\text { Perselisihan akibat dari } \\
\text { kendaraan Ellya Dado } \\
\text { yang dirusak }\end{array}$ & $\begin{array}{l}\text { Mendakwa Ellya Dado } \\
\text { selama } 2 \text { minggu penjara } \\
\text { dengan percobaan } 1 \\
\text { bulan karena telah } \\
\text { mengancam dan } \\
\text { menghina korban. }\end{array}$ & $\begin{array}{l}\text { Hakim menimbang telah } \\
\text { tercapai kesepakatan damai } \\
\text { antar pihak dengan } \\
\text { memperbaiki kerusakan } \\
\text { kendaraan yang berarti tidak } \\
\text { ada kejahatan yang dapat } \\
\text { dihukum pidana lagi. Hakim } \\
\text { menjunjung tinggi kedamaian } \\
\text { dari pada perselisihan yang } \\
\text { berterusan. }\end{array}$ & Lepas & $\begin{array}{l}\text { Bukanlah nilai } \\
\text { permaafan } \\
\text { hakim dalam } \\
\text { putusan } \\
\text { Lepas. }\end{array}$ \\
\hline
\end{tabular}

\footnotetext{
13 Putusan Pengadilan Negeri Jakarta Utara Nomor 90/PID/1976/TIM.

14 Putusan Pengadilan Tinggi Medan Nomor 53/PID/1983/PT Mdn.

15 Putusan Pengadilan Negeri Nomor : 52/PID.SUS/2013/PN.SML

16 Putusan Pengadilan Negeri Jakarta Utara-Timur No.46/PID/78/UT/WANITA.
} 
Dapat ditarik sebuah pemikiran bahwa dan asas hukum pidana yang lebih menjunjung dalam kebijakan formulasi hukum pidana saat ini baik dari Kuhp/WvS dan Undang-undang Khusus diluar Kuhp masih belum memilki dan memasukan secara eksplisit dan jelas ide permaafan hakim bagi pidana yang dipandang ringan dan dipandang tidak perlu dipidanakan. Dapat dikatakan kebijakan formulasi hukum pidana saat ini tidak ada nilai permaafan secara murni dari hakim, hukum pidana saat ini masih menggunakan asas hukum yang kaku "Tiada maaf bagimu" sehingga seakan pidana penjara adalah obat terakhir untuk para pesalah yang melakukan tindak pidana sesuai Kuhp/WvS yang sangat bercorak liberalis. Nilai kemanusiaan yang tertuang dalam Pancasila tidak tercermin dalam Kuhp milik belanda yang saat ini kita gunakan.

\section{Aplikasi nilai permaafan hakim dalam penerapan peradilan pidana di Indonesia.}

Peradilan pidana saat ini banyak memutus kasus yang dipandang oleh masyarakat hanya berpihak pada kalangan atas tapi tidak berprikemanusiaan pada kalangan bawah.Pandangan umum dari masyarakat bahwa hukum saat ini tajam kebawah namun tumpul keatas telah dirasa dalam beberapa putusan yang tidak layak untuk dipersidangkan dan bahkan seharusnya dapat diselesaikan dengan perdamaian.Dampak dari tidak adanya pedoman perdamaian dan kemanusiaan menghasilkan putusan pidana yangdapat menganggu rasa keadilan dan menimbulkan ketidakpercayaan dari masyarakat terhadap peradilan hukum di Indonesia. Pada saat ini ada beberapa putusan peradilan pidana yang dipandang telah memiliki nilai permaafan seperti :

Dapat ditarik sebuah pandangan bahwa pada saat ini tidak ada aplikasi permaafan dalam penerapan peradilan pidana di Indonesia.Walapun sudah ada beberapa putusan dan pertimbangan hakim yang cendrung memilki nilai permaafan namun, permaafan tidak dapat dilakukan oleh hakim karena tidak ada landasan hukum untuk menjatuhkan permaafan dalam Kuhap yang ada hanya Pidana, Bebas, dan Lepas.Hal ini juga terkait pada pedoman pemidanaan yang menjadi induk hukum pidana seperti Kuhp yang seharusnya dimasukan ide permaafan pada pedoman Kuhp Indonesia sehingga seluruh sistem pemidanaan baik materil dan formil dapat menerapkan permaafan guna kedamaian dalam sistem pemidanaannya.

\section{Formulasi Ide Permaafan Hakim dalam RUU KUHP 2015.}

Ruu Kuhp dibentuk untuk menyesuaikan hukum pidana warisan belanda (Kuhp), yang pada harapan besar dapat direformasi ke hukum pidana 
nasional yang sesuai dengan nilai pancasila dan keperluan masyarakat.Reformasi hukum terletak pada aturan umum yang meliputi tujuan, pedoman dan pemidanaan sesuai dengan nilai-nilai kebangsaan. Salah satu ide besar dalam pembentukan konsep ini adalah ide permaafan hakim yang bersifat individual.Ide permaafan hakim yang bersifat individual ini memilki nilai ketuhanan, kemanusiaan dan kemasyarakatan sesuai dengan jiwa kabangsaan (Pancasila).

Konsep Permaafan dalam Ruu Kuhp 2015 diimbangi dengan ide inividualistik yang mana bahwa vonis hakim juga bertitik tolak kepada aspek tujuan pemidanaan yang bertolak pada model sistem peradilan pidana yang mengacu kepada "daad-dader strafrecht" yaitu model keseimbangan kepentingan yang memperhatikan pelbagai kepentingan, meliputi kepentingan negara, kepentingan individu, kepentingan pelaku tindak pidana, dan kepentingan korban kejahatan, sehingga arah yang dicapai akan menghasilkan tujuan yang memberikan kedamaian dan kesejahteraan bagi setiap elemen yang ada. Permaafan hakim dalam pembaharuan pidana merupakan salah satu bentuk dari ide individualisasi pidana yang memperhatikan setiap kepentingan termasuk kepentingan pelaku, oleh karena itu ide permaafan hakim juga disebut sebagai "permaafan individual" dalam pidana Indonesia.
Ide individualisasi pidana ini mengandung beberapa karakteristik seperti pertanggungjawaban pidana yang bersifat pribadi atau perorangan (asas personal), kemudian pidana hanya dapat diberikan kepada orang yang bersalah (asas culpabilitas), selain itu pidana harus disesuaikan dengan karakteristik dan kondisi pelaku, yang berarti ada kelonggaran bagi hakim untuk memilih sanksi pidana dan harus ada kemungkinan untuk memodifikasi pidana berupa penyesuaian dalam

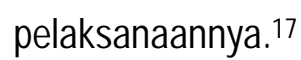

3.1 Pasal 55 dan 56 Ruu Kuhp 2015 sebagai

\section{Tujuan dan Pedoman dalam Permaafan Hakim}

Dalam Ruu Kuhp 2015 tujuan pemidanaan terdapat pada ketentuan umum Pasal 55 dan pedoman pemidanaan dalam ketentuan umum Pasal 56 untuk hakim dapat memaafkan pelaku tindak pidana yang dipandang dapat dimaafkan meskipun jelas bersalah. RUU KUHP 2015 Bab III bagian kesatu tentang tujuan pemidanaan dalam pasal 55 ayat 1 menyatakan pemidanaan bertujuan $: 18$
a. Mencegah dilakukannya tindak pidana dengan menegakkan norma hukum demi pengayoman masyarakat; mengadakan pembinaan sehingga menjadi orang yang baik dan berguna;
b. Memasyarakatkan terpidana dengan

\footnotetext{
${ }^{17}$ Lawrence M. Friedman, American Law: An invaluable guide to the many faces of the law, and how it affects our daily our daily lives, W.W. Norton \& Company, New York, 1984, hlm. 26 ${ }^{18}$ Rancangan undang-undang Kuhp 2015, Pasal 55 ayat 1.
} 
c. Menyelesaikan konflik yang ditimbulkan oleh tindak pidana, memulihkan keseimbangan, dan mendatangkan rasa damai dalam masyarakat

d. Membebaskan rasa bersalah pada terpidana.

Dalam ketentuan tujuan pemidanaan diatas menjelaskan bahwa pemidanaan memilki tujuan yang mulia dengan mencegah pidana demi pengayoman masyarakat.Pemidanaan juga bertujuan membina terpidana untuk menjadi orang baik dan berguna serta pemidanaan bertugas menyelesaikan konflik, memulihkan kesimbangan dan jugamendatangkan rasa damai dalam masyarakat.Tujuan dari pidana diatas mengandung nilai kemasyarakatan yang sesuai dengan karakter bangsa Indonesia (Pancasila), selain itu tujuan diatas lebih integratif dengan lebih berorientasi pada pelaku tindak pidana dibandingkan perbuatan pidana. Pasal 55 ayat 2 juga tidak kalah penting dalam merekonstruksi tujuan pemidanaan karena disebutkan bahwa "pemidanaan tidak dimaksudkan untuk menderitakan dan merendahkan martabat manusia",19hal ini menunjukan bahwa tujuan pemidanaan dalam Kuhp yang akan datang akan sangat berkemanusiaan dan memungkinkan adanya permaafan oleh hakim.

Selain dari tujuan pemidanaan yang dapat memungkinkan permaafan oleh hakim, dalam

${ }^{19}$ Rancangan undang-undang Kuhp 2015, Pasal 55 ayat 2. pedoman pemidanaan yang akan datang jelas menunjukan formulasi pemaafan dalam substansi rumusannya. Dalam Ruu Kuhp 2015 pada pedoman pemidanaan pasal 56 ayat 1 menyatakan dalam pemidanaan wajib dipertimbangkan: 20

a. kesalahan pembuat tindak pidana;

b. motif dan tujuan melakukan tindak pidana;

c. sikap batin pembuat tindak pidana;

d. tindak pidana yang dilakukan apakah direncanakan atau tidak direncanakan;

e. cara melakukan tindak pidana;

f. sikap dan tindakan pembuat sesudah melakukan tindak pidana;

g. riwayat hidup, keadaan sosial, dan keadaan ekonomi pembuat tindak pidana;

h. pengaruh pidana terhadap masa depan pembuat tindak pidana;

i. pengaruh tindak pidana terhadap korban atau keluarga korban;

j. pemaafan dari korban dan/atau keluarganya; dan/atau

k. pandangan masyarakat terhadap tindak pidana yang dilakukan.

Dengan adanya pedoman pemidanaan pada ayat 1 pasal 56 Ruu Kuhp diatas, dapat memungkinkan hakim dalam sistem pemidanaan yang akan datang untuk dapat lebih melihat orientasi kasus pidana pada pelaku tindak pidana tidak hanya pada perbuatanya saja yang melawan undang-undang dan dapat memberi kebebasan pada hakim untuk menilai pelaku bahkan dapat memberikan permaafan bagi pelaku tidak pidana. Pedoman pemidanaan diatas dapat menjadi acuan bagi penegak hukum dalam menjalankan tugasnya

\footnotetext{
${ }^{20}$ Rancangan undang-undang Kuhp 2015, Pasal 56 ayat 1.
} 
untuk menemukan keadilan dan tidak hanya hukuman pidana pada terdakwa meskipun telah terpaku pada kepastian undang-undang.

Dalam pedoman pemidanaan pasal 56 ayat 2 Ruu Kuhp menyatakan "Ringannya perbuatan, keadaan pribadi pembuat, atau keadaan pada waktu dilakukan perbuatan atau yang terjadi kemudian, dapat dijadikan dasar pertimbangan untuk tidak menjatuhkan pidana atau mengenakan tindakan dengan mempertimbangkan segi keadilan dan kemanusiaan". ${ }^{21}$ Dengan dasar ini maka hakim di masa mendatangakan memiliki Legal standinguntuk dapat memaafkan orang yang nyata-nyata melakukan tindak pidana dengan alasan keadaan pribadi si pembuat dan pertimbangan kemanusiaan.

Ketentuan pengampunan oleh hakim tersebut tidak ada dalam Kuhp saat ini.Pasal 56 ayat 2 Ruu Kuhp 2015 ini seakan menegaskan sebuah kemungkinan yang dapat menyimpulkan bahwa dengan berpegang pada tujuan pemidanaan pada pasal 55 dan mengacu pada pedoman pemidanaan yang berorientasi pada pelaku dalam pasal 56(1), maka sistem pemidanaan di Indonesia nantinya akan dapat memaafkan pelaku pidana dengan mempertimbangkan segi keadilan dan segi kemanusiaan.

Pengaturan ini memberikan kemungkinan bagi hakim untuk tidak melanjutkan penjatuhan terbukti melakukan suatu tindak pidana yang ringan dan tidak serius, apabila hakim menganggap patut berhubungan dengan kecilnya arti perbuatan, kepribadian pelaku atau keadaan-keadaan pada waktu perbuatan dilakukan, begitu pula sesudah itu ia menunjukkan keteladanan, hakim dapat menentukan di dalam putusan bahwa tidak ada pemidanaan atau tindakan yang dijatuhkandengan mempertimbangkan segi keadilan dan kemanusiaan. ${ }^{22}$ Meskipun telah memilki ketentuan peramaafan dalam pedoman pemidanaan, terdapat beberapa poin pembatasan agar majelis hakim dapat menjatuhkan putusan berupa pardon yaitu :

1. ringanya perbuatan.

2. ringannya keadaan pribadi pembuat.

3. ringannya keadaan pada waktu dilakukan perbuatan, atau yang terjadi kemudian.

4. dengan memperhatikan dan mempertimbangakan segi keadilan dan kemanusiaan.

Dengan ketentuan diatas hakim diberi wewenang untuk dapat memberikan maaf, apabila hakim merasa pemberian pidana akan mengusik keadilan dan kemanusian, apabila hakim merasa bahwa ada pertentangan antara kepastian hukum dan keadilan, maka hakim dapat memilki keleluasaan untuk tetap membela pada keadilan.

22Andi Zainal Abidin dan Andi Hamzah, Pengantar Dalam Hukum Pidana Indonesia, (Jakarta: Yarsif Watampone, 2010), hal $170-171$. 
Asas permaafan hakim atau disebut dilakukan seseorang, sebagai bentuk rechterlijk pardon/judicial pardon dalam pedoman pengampunan maka dengan adanya pemaafan pemidanaan dilatarbelakangi oleh falsafah ide atau seseorang yang bersalah tidak perlu dijatuhi pokok pemikiran untuk menghindari hukuman atau tidak perlu merasakan hukuman kekakuan/absolutisme dalam sistem pemidanaan terlebih lagi pada hukuman penjara yang yang dijalankan oleh aparat penegak hukum, selain seharusnya menjadi pilihan terakhir dalam itu melihat pada kondisi muatan penjara yang tidak paradigma alternatif pidana, pemberian maaf dapat menampung karena seakan penjara dicantumkan dalam putusan hakim, dan tetap harus merupakan obat satu-satunya bagi terpidana. Hal ini dinyatakan bahwa terdakwa terbukti melakukan merupakan bentuk koreksi judisial terhadap asas legalitas (judicial corrective to the legality principle) yang tidak sesuai dengan pengimplementasian atau pengintegrasian nilai atau paradigma dalam Pancasila.

Pengimplementasian atau pengintegrasian tujuan pemidanaan yang bernilaikan pancasila ke dalam syarat pemidanaan merupakan bentuk pembaharuan konsep agar hakim dalam memberikan permaafan/pengampunan harus mempertimbangkan tujuan pemidanaan dengan menyediakan klep/katup pengaman (veiligheidsklep) atau pintu darurat (noodeur) dalam pemidanaan, artinya meskipun konsekuensi negara hukum civil law yang menjunjung tinggi kepastian dalam implementasi legalitas namun, ada alternative opsional dalam penerapan yang memperbolehkan suatu permaafan dalam keadaan penting atau yang menyangkut keadilan umum.

Pemafaan merupakan suatu bentuk pengampunan/pembebasan dari kesalahan yang tindak pidana yang didakwakan kepadanya.

Pada prinsipnya, Kuhp tidak mengatur tentang pemaafan oleh hakim.Hal ini terjadi disebabkan karena Kuhp sendiri merupakan sebuah sistem pemidanaan substantif yang kaku dan bertolak dari tiga masalah hukum pidana, yaitu tindak pidana (strafbaarfeit), kesalahan (schuld), dan pidana (straf/punishment/poena). ${ }^{23}$ Dalam skema pemidanaan akan terlihat seperti :

Pidana $=$ Tindak pidana + Kesalahan (Pertanggungjawaban pidana)

Dalam pola formulasi atau model Kuhp/WvS di atas, tidak tergambar adanya variable tujuan pemidanaan, kerana tidak dirumuskan secara eksplisit adanya tujuan dalam Kuhp, sehingga terkesan "tujuan" berada diluar sistem dan jelas banyak dihiraukan atau dilupakan oleh penegak hukum. Dengan model demikian, seolah-

${ }^{23}$ Tim Penyusun RKUHP Naskah Akademis RKUHP., hlm. 18. Sebagaiman dikutip dari Barda Nawawi, Tujuan dan Pedoman Dalam Konsep RUU KUHP termuat dalam Mardjono Reksodiputro (Pengabdian Seoarang Guru Besar Pidana).,(Depok: Badan Penerbit FHUI, 2007)., hlm. 63. 
olah dasar pembenaran atau justifikasi adanya pidana hanya terletak pada unsur tindak pidana sebagai syarat objektif atau dasar pembenar dan unsur kesalahan sebagai syarat subjektif atau dasar pemaaf. ${ }^{24}$

Pandangan bahwa pidana sebagai konsekuensi absolut yang harus ada terwujud apabila kedua syarat tersebut telah terbukti, namun hakim seharusnya dapat melihat suatu kesalahan yang dapat diberi maaf atau tidak perlu dipidana demi keadilan, hal tersebut pun sulit diterapkan karena model Kuhp saat ini yang absolut/kaku membuat ide permaafan tidak mendapat tempat dan sukar diterima tanpa ada formulasi yang jelas. Kerangka berpikir seperti ini memberikan suatu legitimasi bahwa Kuhp/WvS saat ini bersifat "model kepastian" yang kaku.25Model kepastian hukum menurut penulis adalah bentuk jati diri/wujud dari konsekuensi adanya negara hukum yang menjalankan hukum atau aturan yang dikodifikasi sebagai jaminan kejelasan dengan diakuinya sebuah aturan hukum pada saat suatu hukum akan dijalankan, karena tanpa kejelasan dari kepastian hukum yang dikodifikasi maka hukum akan menjadi tidak jelas dan tidak dapat dijalankan dengan baik.

${ }^{24}$ Barda Nawawi, Tujuan dan Pedoman Dalam Konsep RUU KUHP 2012 hlm.63

${ }^{25}$ Saur menyebutnya sebagai "trias hukum pidana" (berupa sifat melwan hukum, kesalahan, dan pidana) dan Pecker menyebutnya sebagai "the three concept" atau "the three basic problems"(berupa Offence, guilt, dan punishment)" Herbert L. Packer, the Limits of The Criminal Sanction, ( Stanford: Stanford University Press, 1968).,hlm.17
Ruu Kuhp kedepannya harus tetap mendasari dari sifat "model kepastian" karena telah menjadi konsekuensi logis sebagai negara hukum agar hukum dapat dijalankan dengan jelas dan tegas, akan tetapi sifatnya yang saat ini kaku harus dirubah atau disesuaikan menjadi fleksibel dan sejalan dengan keadilan sosial. Menurut penulis, katup/alternative pengaman yang ditunjukan pada hukum pidana yang kaku saat ini sebenarnya ditunjukkan untuk menjawab kasus-kasus yang sebenarnya tidak layak untuk diteruskan atau dijatuhkan suatu pemidanaan meskipun telah terbukti bersalah.

Oleh karenanya, masalah tujuan dan asas pemidanaan yang cendrung diharamkan pada Kuhp saat ini, sebaiknya diatur secara ekspilsit dalam Ruu Kuhp mengingat perannya yang sentral dalam suatu sistem peradilan pidana, khususunya dalam hal permaafan hakim. Dengan adanya penegasan norma "tujuan pemidanaan" dalam Kuhp yang akan datang (seperti pada pasal 55 Ruu Kuhp 2015) maka skema pemidanaan akan terlihat seperti pada gambar dibawah :

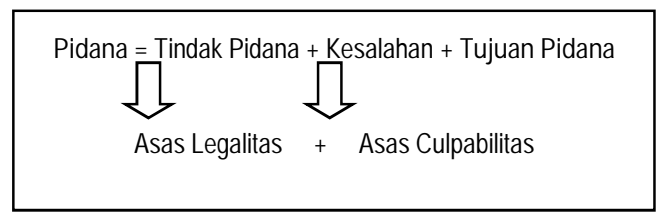

Dengan gambar diatas apabila diterapkan secara eksplisit pada Kuhp yang akan datang maka tujuan pidana menjadi syarat berlakunya suatu 
pemidanaan. Hal ini juga menegaskan bahwa pelaku yang dimaafkan dan tidak dipidana (seperti pada pasal 56 (2) Ruu Khup 2015) akan mempunyai tempat yang lebih jelas dengan adanya rumusan "tujuan" dalam sistem induk sehingga peradilan pidana yang akan datang akan lebih sesuai dengan cita-cita bangsa. Dengan adanya tujuan dalam pemidanaan jelas akan menciptakan karakter hakim yang lebih menahan nafsu untuk memenjarakan dan akan lebih mewujudkan efektivitas pemidanaan dengan memperhatikan nilai-nilai integral, progessivitas dan individual pelaku sesuai dengan sistem hukum nasional yaitu Pancasila.

Dengan demikian, ide pemaafan hakim yang dilengkapi pedoman dan tujuan dalam sistem induk akan mungkin dapat dilaksanakan oleh Majelis Hakim. Dengan dimasukkannya variabel tujuan di dalam syarat pemidanaan maka menurut konsep RKUHP yang akan datang, dasar pembenaran atau justifikasi dari adanya pemidanaan, tidak hanya pada "tindak pidana" (syarat objektif/legalitas) dan "kesalahan" (syarat subjektif/culpabilitas), tetapi juga pada "tujuan/pedoman pemidanaan".

Dengan mengingat "tujuan dan pedoman pemidanaan" maka dalam kondisi tertentu hakim tetap diberi kewenangan untuk memberi maaf dan tidak menjatuhkan pidana atau tindakan apapun (non imposing of a penalty), ${ }^{26}$ walaupun "tindak pidana" dan "kesalahan" telah terbukti. Dengan adanya pedoman untuk tidak menjatuhkan pidana maka pengadilan akan menjadi lebih berkemanusiaan, dapat dikatakan bahwa secara konseptual telah ada pergeseran yang saat ini bersifat kaku/absolut akan berubah menjadi model keseimbangan yang fleksibel. ${ }^{27}$

Setiap sistem seharusnya memilki sebuah tujuan yang pasti, dan sebuah sistem hukum harus memilki tujuan, maka dikatakan apabila sistem hukum pidana merupakan bagian dari sebuah sistem ia harus menjadi sistem yang bertujuan (purposive system). ${ }^{28}$ Agar terwujudnya keterjalinan sistem, maka tujuan pemidanaan seharusnya dirumuskan secara eksplisit di dalam Kuhp yang akan datang seperti yang tergambar dalam Ruu Kuhp 2015 yang saat ini merupakan rancangan konsep terbaru. Dalam pembaharuan sistem tersebut dimaksudkan agar rumusan yang eksplisit

${ }^{26}$ non imposing of penalty adalah dimana seoarang terdakwa terbukti bersalah, tetapi tidak dijatuhkan pemidanaan oleh Majelis Hakim. Pengertian dari non imposing of penalty/ Rechterlijk Pardon/ dispensa de penamempunyai tujuan yang sama, yakni menyatakan seseorang terbukti secara sah dan meyakinkan, namun tidak menjatuhkan pemidanaan. Walaupun pemaknaan secara filosofis dari non imposing of penalty belum tentu didasarkan oleh konsepsi pemaafan hakim (bisa didasarkan hanya dari permasalahan penjara pendek, tetapi ketiganya mempunyai maksud yang sama untuk tidak menjatuhkan pidana sekalipun terdakwa terbukti). ${ }^{27}$ Marcus Priyo Gunarto, Asas Keseimbangan Dalam Konsep Rancangan Undang-Undang Kitab Undang Hukum Pidana, Jurnal Mimbar Hukum UGM, Volume 24 Nomor 1 Februari 2012, hlm 86-96.

${ }^{28}$ Anthony Allot, The Limits of Low, Butterwoth \& Co. Ltd, London, 1980,hlm.28 
itu tetap dilaksanakan dan tidak dilupakan, terutama untuk menegaskan bahwa tujuan pemidanaan merupakan bagian integral dari sistem pemidanaan. Dengan adanya penegasan tersebut, maka posisi tujuan dan asas pedoman pemidanaan dalam persyaratan pemidanaan dapat terwujud kearah yang lebih baik.

\subsection{Pasal 72 Ruu Kuhp 2015 sebagai Asas}

\section{Permaafan dalam Pelaksanan Pidana}

Selanjutnya pada buku I bagian kedua dalam paragraf kedua Ruu Kuhp 2015 tepatnya pada pasal 72 tentang pidana penjara yang juga telah memasukan pedoman pidana yang berkaitan dengan ide permaafan atau tidak dijatuhkannya pidana jika dijumpai hal-hal yang terdapat pada ketentuan formulasi pasal 72 ayat 1 Ruu Kuhp 2015 seperti : 29

(1) Dengan tetap mempertimbangkan Pasal 55 dan Pasal 56, pidana penjara sejauh mungkin tidak dijatuhkan, jika dijumpai keadaan-keadaan sebagai berikut:

a. terdakwa berusia di bawah 18 (delapan belas) tahun atau di atas 70 (tujuh puluh) tahun;

b. terdakwa baru pertama kali melakukan tindak pidana;

c. kerugian dan penderitaan korban tidak terlalu besar;

d. terdakwa telah membayar ganti kerugian kepada korban;

\footnotetext{
${ }^{29}$ Rancangan undang-undang Kuhp 2015, Pasal 72 ayat $1 .$.
}

e. terdakwa tidak mengetahui bahwa tindak pidana yang dilakukan akan menimbulkan kerugian yang besar;

f. tindak pidana terjadi karena hasutan yang sangat kuat dari orang lain;

g. korban tindak pidana mendorong terjadinya tindak pidana tersebut;

h. tindak pidana tersebut merupakan akibat dari suatu keadaan yang tidak mungkin terulang lagi;

i. kepribadian dan perilaku terdakwa meyakinkan bahwa ia tidak akan melakukan tindak pidana yang lain;

j. pidana penjara akan menimbulkan penderitaan yang besar bagi terdakwa atau keluarganya;

$\mathrm{k}$. pembinaan yang bersifat non-institusional diperkirakan akan cukup berhasil untuk diri terdakwa;

1. penjatuhan pidana yang lebih ringan tidak akan mengurangi sifat beratnya tindak pidana yang dilakukan terdakwa;

m. tindak pidana terjadi di kalangan keluarga; atau

n. terjadi karena kealpaan.

Pada ketentuan formulasi diatas menjelaskan bahwa ide permaafan telah lebih ditekankan pada proses pemidanaan dalam bentuk jenis-jenis pidana yang terperinci seperti dalam huruf a sampai n dalam pasal 72 (1) Ruu Kuhp ini. Ketentuan pasal 72(1) ini seakan memberi perluasan makna permaafan bagi hakim dalam kewenangan barunya selain ter-eksplisit pada pasal 55 sebagai tujuan dan pasal 56 sebagai pedoman, hakim ditekankan kembali untuk dapat tidak menjatuhkan pidana dalam pasal 72 (1), sehingga hakim dapat lebih memprioritaskan permaafan yang 
cenderung memiliki nilai perdamaian bagi keadilan dan kemanusiaan yang dicintai oleh masyarakat pada umumnya.

Pasal 72 ayai 1 telah menjawab persoalan hukum pidana yang selama ini dipandang oleh masyarakat tidak dapat diselesaikan oleh peradilan yang cendrung absolut/kaku tidak memihak pada masyarakat kecil dan tidak sesuai dengan hati nurani masyarakat. Namun, Ketentuan pasal ini menurut penulis memberi keharusan bagi hakim untuk tetap mempertimbangkan Pasal 55 dan Pasal 56 agar bentuk permaafan yang dihasilkan memang sesuai dan pantas untuk dimaafkan oleh hakim. Artinya tidaklah menjadi kelemahan bagi peradilan untuk memafkam kasus-kasus dengan mudah tetapi mengharuskan hakim dapat jeli melihat fenomena hukum yang benar-benar mengusik keadilan yang hidup di masyarakat sesuai dengan ketentuan pasal 72 ini.

Dalam Pasal 72 ayat 2 kembali menekankan dengan menjelaskan batas dan kualifikasi pidana dengan sangat tegas bahwa "Ketentuan sebagaimana dimaksud pada ayat (1) tidak berlaku bagi tindak pidana yang diancam dengan pidana penjara di atas 5 (lima)tahun atau diancam dengan pidana minimum khusus atau tindak pidana tertentu yang sangat membahayakan atau merugikan masyarakat atau merugikan keuangan atau perekonomian negara". 30

Menurut penulis dalam hal ini perancang konsep menunjukan bahwa permaafan juga tidak dapat dengan mudah diputuskan oleh sembarang kasus, adanya spesifikasi khusus dalam formulasi yang tertuang pada pasal 72 ayat 2 menurut penulis hal inimenunjukan bahwa permaafan hanya berlaku pada kasus-kasus tertentu yang memang dipandang perlu (sesuai pasal 72(1) bagi keadilan masyarakat dan kepentingan umum/negara. Dengan ter-eksplisitnya ketentuan-ketentuan formulasi mengenai ide permaafan oleh hakim dalam Ruu Kuhp yang baru ini maka permaafan dapat dijalankan dalam sistem peradilan secara integral dengan baik tanpa merusak nilai kepastian dalam berhukum.

Hadirnya ketentuan formulasi tentang pembatasan pidana pada pasal 72 Ruu Kuhp 2015 adalah sebuah asas baru dalam rancangan undang-undang pidana yang disusun selama ini. Dimasukannya pedoman untuk tidak menjatuhkan pidana dalam pasal ini menunjukan pemikiran si pembuat konsep bahwa hukuman penjara seakan menjadi suatu hal yang wajib dalam hukum pidana, hampir seluruh ketentuan undang-undang yang berunsur pidana mengenakan hukuman penjara dalam tiap delik dan sanksinya dengan perumusan

\footnotetext{
30Rancangan undang-undang Kuhp 2015, Pasal 72 ayat 2.
} 
tunggal tanpa ada alternative dan solusi lain untuk menyelesaikannya..

Masalah-masalah pada kasus-kasus kecil yang salah satunya seperti pencurian termasuk yang ramai memenuhi penjara dan tidak dapat diselesaikan. Penjara seakan satu-satunya jalan untuk membasmi kejahatandi bumi pertiwi, dan hal ini dirasai sangat kaku dan sangat imperative, sedangkan muatan penjara sangatlah terbatas hal ini lah yang menjadi landasan bahwa ada yang salah dalam sistem perumusan pidana saat ini dan perlu ada rekonstruksi secara fundamental.

Pedoman yang dituangkan pada pasal 72 ini juga mengandung 2 asas yang sangat akrab dengan ide permaafan hakim dan tidak hanya berpusat pada hukuman penjara.Kedua asas atau prinsip yang dapat dijabarkan dalam muatan pasal 72 ini menurut Barda Nawawi dalam kuliah umumnya juga mengandung asas penghematan (parsimony principle) dan asas menahan diri (restraint principle). Kedua asas ini lebih pada pengaturan dari kebiasaan aparat penegak hukum yang cendrung menghukum, pada asas penghematan mengandung arti aparat penegak hukum tidak dapat mengobral sanksi penjara semaunya, khususnya hakim yang harus mempertimbangkan banyak hal termasuk alternatif sanksi lain seperti permaafan sebelum menjatuhkan pidana penjara, asas ini menjadi pedoman agar hakim mengurangi hasrat untuk memenjarakan orang. Jangan sampai semua pelaku tindak pidana dari semua jenis pidana harus berujung ke penjara karena penjara seharusnya adalah hukuman terakhir (last resort).

Pada kandungan asas kedua yaitu asas menahan diri yang bermakna aparat penegak hukum khususnya hakim harus berhati-hati menggunakan hukuman penjara. Secara teoritis, hukuman penjara bisa berdampak positif seperti menimbulkan efek jera dan mengurangi potensi kejahatan yang dilakukan pelaku, namun dapatjugaberdampak negatif kalau dipakai sembarangan dan terkesan memaksakan kehendak.Dengan kedua kandungan asas yang terdapat pada pasal 72 ini menurut penulis, permaafan menjadi salah satu alternative wayatau problem solvingdalam mengurangi dan menyeleksi hukuman penjara.

Dalam penjatuhan pidana, menurut penulis hukuman yang bersifat penderitaan seperti penjara harus diposisikan sebagai alternatif yang dapat dipakai jika tidak ada hukuman yang lebih baik dan bijaksana untuk di putus.Dalam pemberian pidana upaya pertama ialah memberi dan membawa kesadaran kepada si terhukum, dengan mempertimbangkan aspek-aspek yang bersifat non yuridis seperti aspek psikologis terdakwa, sosial ekonomis, agamis, aspek filsafat humanis, aspek keadilan korban dan masyarakat, aspek policy/filsafat pemidanaan, aspek disparitas 
pemidanaan,dan lain sebagainya maka hendaknya vonis diharapkan memenuhi seluruh dimensi keadilan.

Secara menyeluruh dengan adanya tujuan dan pedoman dalam Kuhp yang akan datang, putusan hakim yang akan datang juga dapat mempertimbangkan aspek bersifat yuridis, sosiologis dan filosofis sehingga keadilan yang ingin dicapai, diwujudkan dan dipertanggungjawabkan adalah keadilan dengan orientasi pada moral justice, sosial justice dan legal justice. Dengan formulasi baru dalam Ruu Kuhp 2015 ini diharapkan ide permaafan hakim dapat memulihkan segala kerusakan yang terjadi akibat pidana dan menjadi cermin pemidanaan yang lebih berkemanusiaan sesuai dengan wujud falsafah Pancasila, serta dapat dilaksanakan dengan baik sesuai dengan tujuan dari hukum pidana.

\section{Kesimpulan dan Saran}

\section{Kesimpulan}

Dapat disimpulkan bahwa hasil analisis kajian pada pembahasan penelitian ini ditemukannya 6 (enam) Pasal yang berkaitan dengan nilai permaafan dalam formulasi KUHP dan UU diluar KUHP saat ini, namun bukanlah nilai permaafan yang murni dapat dimaafkan oleh hakim dan ditemukannya 5 (lima) aplikasi penerapan putusan peradilan pidana yang telah memiliki nilai permaafan, namun masih belum dapat diterapkan dengan baik karena formulasi hukum saat ini masih sangat kaku/indvidualistik. Hasil penelitian menemukan bahwa baik dari tahap formulasi dan aplikasi hukum pidana saat ini adalah tidak memiliki nilai permaafan dari hakim. Diformulasikannya ide permaafan hakim "Rechterlijk Pardon" dengan memasukannya tujuan dan asas pemidanaan dalam syarat pemidanaan yaitu pada Pasal 55, 56 dan 72 RUU KUHP 2015, yang nantinya akan menjadikan sistem hukum pidana di Indonesia yang akan datang yang lebih integral, fleksible, humanis, progress dan nasionalis.

\section{Saran}

Demi mewujudkan pidana yang lebih berketuhanan, berkemanusiaan dan berkemasyarakatan sesuai dengan nilai hukum nasional yaitu Pancasila, disarankan kepada para legislator sebagai wakil rakyat untuk memperbaharui sistem induk pidana (KUHP) yang saat ini dirasa kaku dan tidak memiliki nilai permaafan dalam formulasinya, dengan memasukan tujuan dan asas pemidanaan dalam formulasi KUHP yang akan datang maka ide permaafan yang merupakan terobosan hukum dalam mencari keadilan masyarakat Indonesia dapat diwujudkan secara nyata, DPR harus dapat melihat keperluan hukum pidana pada saat ini, yang memerlukan pembaharuan signifikan untuk 
tercapainya sistem peradilan pidana yang lebih efektif di Indonesia. Dengan adanya tujuan dalam konsep pemidanaan akan menciptakan karakter hakim yang lebih menahan nafsu untuk memenjarakan dan akan lebih mewujudkan efektivitas pemidanaan dengan memperhatikan nilai-nilai integral, progessivitas dan individual pelaku sesuai dengan sistem hukum nasional yaitu Pancasila.

\section{Daftar Pustaka}

Abidin Andi Zainal dan Andi Hamzah, 2010, Pengantar Dalam Hukum Pidana Indonesia, Jakarta:Yarsif Watampone.

Arief. Barda Nawawi. 2015, IImu Hukum Pidana Integralistik,Semarang: Pustaka Magister. .2014, Masalah penegakan Hukum dan Kebijakan Pidana, Jakarta: Kencana. 2012, RUU KUHP Baru sebuah rekonstruksi pidana Indonesia, Semarang: UNDIP.

2011, Pendekatan keilmuan dan Religius dalam Reformasi Penegakan Pidana Indonesia, Semarang: UNDIP. Ibrahim.Johnny,2005, Teori dan Metodologi Penelitian Hukum Normatif, Surabaya: Bayumedia Publishing.

Muladi, 1990. Proyeksi Hukum Pidana Materiil Indonesia Di Masa Datang, Bandung: Alumni.
Muladi dan Barda Nawawi Arief, 1992. Teori-teori dan Kebijakan Pidana, Bandung: Penerbit Alumni.

Priyo Gunarto Marcus,2012. Asas Keseimbangan Dalam Konsep Rancangan UndangUndang Kitab Undang Hukum Pidana, Jurnal Mimbar Hukum UGM, Volume 24 Nomor 1.

\section{Peraturan Perundang-undangan.}

Undang-Undang Nomor 11 tahun 2012 Sistem

Peradilan Anak.

Undang-Undang Nomor 11 Tahun 2012 Tentang

Pembentukan Peraturan UU

Undang-Undang Nomor 48 Tahun 2009 Tentang

Kekuasaan Kehakiman.

Undang-Undang No 22 tahun 2002 Tentang

Pengampunan Presiden (Grasi).

Kitab Undang-Undang Hukum Pidana (KUHP/Wvs).

Kitab Hukum Acara Pidana (KUHAP)

Program Legislasi Nasional Tahun 2015-2019.

Naskah Rancangan Undang-Undang KUHP Tahun 2015. 